\title{
An Ice Drift Measurement in Western Parry Channel
}

\author{
R. I. VERRALL, J. H. GANTON and A. R. MILNE ${ }^{1}$
}

\begin{abstract}
A description is given of the drift of ice in Western Parry Channel during the spring and summer of 1970 . Ice-buoys, planted in the fast ice of this region in April 1970, were located at approximately two-week intervals by Canadian Forces aircraft overflights. The ice in M'Clure Strait drifted to the west, whereas in Viscount Melville Sound the ice drift seemed to have no definite trend. The drift after the middle of July when the ice was broken was compared to the ice motion calculated using Zubov's rule. The comparison yields a respectable agreement. Also, information pertaining to the longevity of ice-buoys in both polar and winter ice is given.
\end{abstract}

RÉSUMÉ. Une mesure de la dérive de la glace dans l'ouest du détroit de Parry. Les auteurs décrivent la dérive de la glace dans l'ouest du détroit de Parry au cours du printemps et de l'été de 1970. Des bouées à glace, plantées dans la glace fixée de cette région en avril 1970, ont été localisées à intervalle approximatif de deux semaines par des survols d'avions des Forces armées canadiennes. La glace dérivait vers l'ouest dans le détroit de M'Clure alors que dans le détroit de Melville la dérive ne semblait pas avoir de direction définie. Les auteurs ont comparé la dérive postérieure à la mi-juillet de la glace fragmentée, au mouvement de la glace calculé selon la règle de Zubov: cette comparaison donne une concordance respectable. De même, les auteurs peuvent apporter des renseignements sur la longévité des bouées à glace, aussi bien dans la glace polaire que dans la glace d'hiver.

РЕЗЮМЕ. Наблюдения за дрейфом льдов в западной иасти пролива Парри. Дано описание дрейфа льдов в западной части прол. Парри весной и летом 1970 г. Положение ледовых буев, вмороженных в припайный лед этого района в апреле 1970 г., повторно, через примерно двухнедельные интервалы, определялось с воздуха во время облётов самолетами Канадских ВВС. В прол. Мак-Клур лед дрейфовал в западном направлении, тогда как в прол. Мелвилл дрейф льдов как будто не имеет отределенного направления. Сравнение фактического дрейфа, имевшего место после середины июля, когда лед был взломан, с движением льдов, рассчитанным на основе правила Зубова, дало удовлетворительную сходимость. Приведены также данные о длительности периода работы ледовых буев, установленных на сезонных и полярных льдах.

\section{INTRODUCTION}

During the summer of 1970, the Defence Research Establishment Pacific monitored the flow of ice in the western region of Parry Channel by following the drift of ice-buoys.

In the Canadian Arctic Archipelago, little is known of the individual effects on the ice of the wind stress, the water stress, and the influence of land which is made manifest as internal ice stresses. Also, little is known of the ocean currents in much of the archipelago. In order to simplify the analysis of the ice drift, a region was chosen for investigation where currents were known to be small and would not contribute appreciably to the net ice motion.

1Defence Research Establishment Pacific, Victoria, B.C., Canada. 


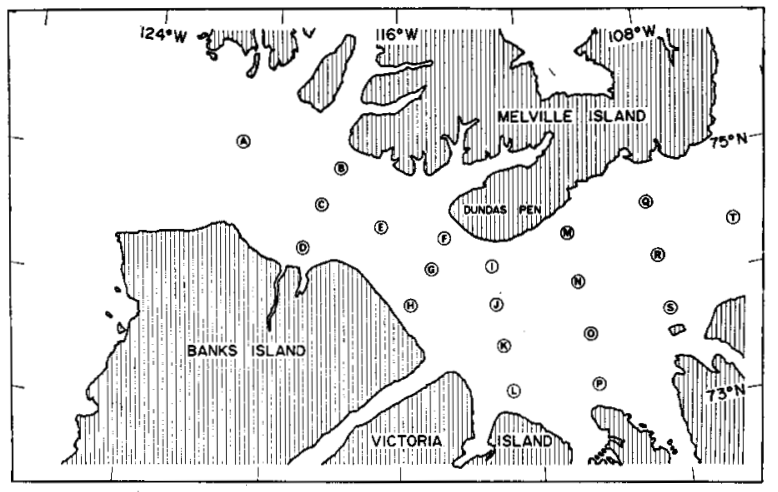

FIG. 1. Estimated original positions of the 20 ice-buoys.

This paper reports the observed motion of the ice-buoys and correlates that motion with the wind as calculated from available atmospheric pressures. All distances are given in nautical miles.

\section{POSITIONING AND RELOCATION OF THE BUOYS}

In April 1970, 20 ice-buoys were implanted in the fast ice of M'Clure Strait and western Viscount Melville Sound, approximately half of them in first-year ice and half in multi-year ice (Fig. 1). At the same time 4 recording barographs were mounted on the surrounding islands so that an accurate record of the local mean sea-level pressure field could be obtained.

Using Canadian Forces Argus aircraft, the positions of the ice-buoys were determined at approximately 2-week intervals, from 12 May until 19 September. The buoys were located and pinpointed on the map in the following way. The aircraft homed-in on the radio transmitter carried by the ice-buoy, and at the "on top" position the aircraft's radar Plan Position Indicator was photographed. Slides made from these photographs were projected onto a map of the area upon which points of radar significance had been marked. The map was moved about until the picture and the map were coincident, whereupon the centre of the picture was marked on the map. The accuracy in the plotted buoy positions depended mainly on the existence of sharp radar returns from enough headlands to enable the picture to be positioned accurately on the map. This condition was satisfied better for some buoy positions than for others. The error in obtaining a picture at the exact "on top" position is not considered to be critical. Depending on the circumstances, the probable error ranged between 1 and 5 miles. For comparison, the arrow heads in Fig. 2 are 5 miles long.

\section{RESULTS}

The motion of the buoys during the months of May, June and July did not take them farther than 5 miles from the positions determined on the first overflight. This lack of motion might be expected during the early months since the ice cover was complete and was restricted by the land. For the remaining period, from the 


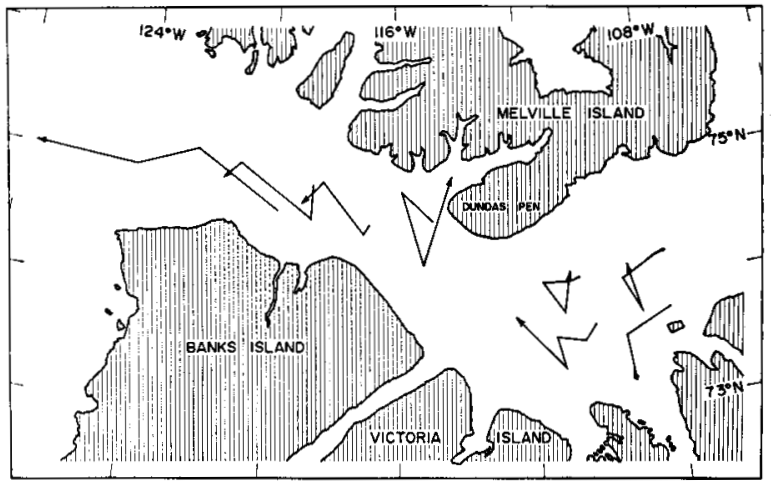

FIG. 2. Observed buoy drift from 21 July to 19 September, 1970.

beginning of August until 19 September, a composite map showing the drift of the ice-buoys is shown in Fig. 2. Here it is evident that the ice cover is more broken and the individual floes were more readily driven by the wind. The average daily travel for each of the intervals between overflights was less than one half mile until mid-July. By mid-August, when the ice cover was completely loose, the average daily travel increased to 3 or 4 miles. In Viscount Melville Sound, the motion during the summer was erratic; there seemed to be only a slight westerly drift. In M'Clure Strait, however, the westerly drift was more definite and increased towards the west.

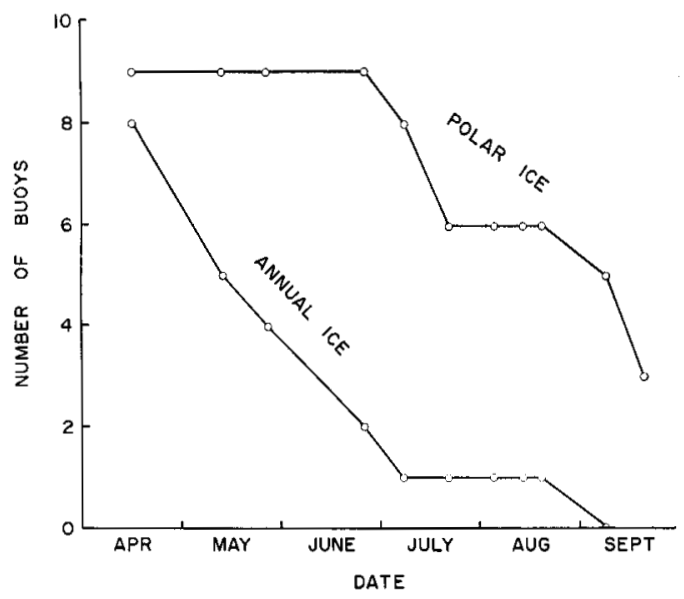

FIG. 3. Number of surviving buoys $v$. the date.

It is interesting to compare the survival times of the ice-buoys mounted in multiyear ice versus those mounted in first-year ice. Fig. 3 shows the survival rate. Multi-year ice, being both thicker and less saline than the annual ice, is significantly stronger and protected the ice-buoys against crushing. The majority of the missing ice-buoys, whether in multi-year or in first-year ice, were lost before the onset of large-scale movements of the ice, suggesting that the destruction mechanism was that of the small scale grinding motion. 


\section{THEORETICAL PREDICTIONS OF ICE DRIFT}

One approach to the calculation of ice drift in the open ocean is to use Zubov's Rule (Zubov 1943), which states that the ice moves in the same direction as the geostrophic wind (parallel to the isobars) and with a speed of approximately 1 per cent of this wind. It is interesting to examine the extent to which this relatively simple theory will predict the motion of ice in Parry Channel, where one would expect the proximity of land to be an important consideration.

The geostrophic wind speed is given by

$$
\mathrm{W}=\frac{1}{2 \omega \rho \sin \phi} \mid \nabla \mathrm{P}
$$

where $\omega$ is the angular velocity of the earth's rotation, $\rho$ is the density of air, $\phi$ is the geographic latitude, and $\nabla \mathrm{P}$ is the horizontal gradient of the atmospheric pressure.

A difficult aspect of the problem was the procurement of a good pressure map. Unfortunately, the 4 barographs which had been set out to obtain an accurate measurement of the local pressure had all failed, primarily because arctic foxes had chewed the unarmoured battery leads. This left only the widely spaced meteorological stations as sources of data. The weather station pressures used in the analysis were from: Isachsen, Mould Bay, Resolute, Sachs Harbour, Cape Parry, Cambridge Bay, Gladman Point, Arctic Bay and Rea Point. Pressures for the first 4 stations were obtained from the appropriate issue of "Arctic Summary" published by the Department of Transport. Pressures for the last 5 stations were provided by the Arctic Weather Central, Department of the Environment, Edmonton. All pressures were tabulated at identical 6-hourly intervals. For each set of pressures a pressure surface was numerically smoothed over a horizontal grid, using a published computer program (Taylor et al. 1971). The map projection used to plot geographic positions was a Lambert conformal conic projection with a standard parallel of latitude of $74^{\circ}$. For each pressure surface, the horizontal pressure gradient was calculated at the ice-buoy positions and from this the velocity of the ice drift at each buoy was calculated using Zubov's rule. This velocity of drift was assumed to remain constant for the following 6 hours, whereupon another pressure surface became available. The calculation was then repeated and applied to the last calculated position of each ice-buoy.

By this procedure the path of each buoy for time intervals between overflights was calculated and compared to the observed position of the buoy. Comparisons are valid only for August and September, when the ice had broken, and only these cases are shown. Figs. 4 to 7 show comparisons of the observed positions and calculated paths for these 4 late summer intervals. To aid the eye, in each figure the observed buoy positions are joined with a straight line; the calculated motion is shown as a dotted line. The agreement with Zubov's rule is reasonable, considering that the effect of the land on both the wind and the internal ice stress is not known, and that pressure maps are not reliable in detail in the region of interest. 


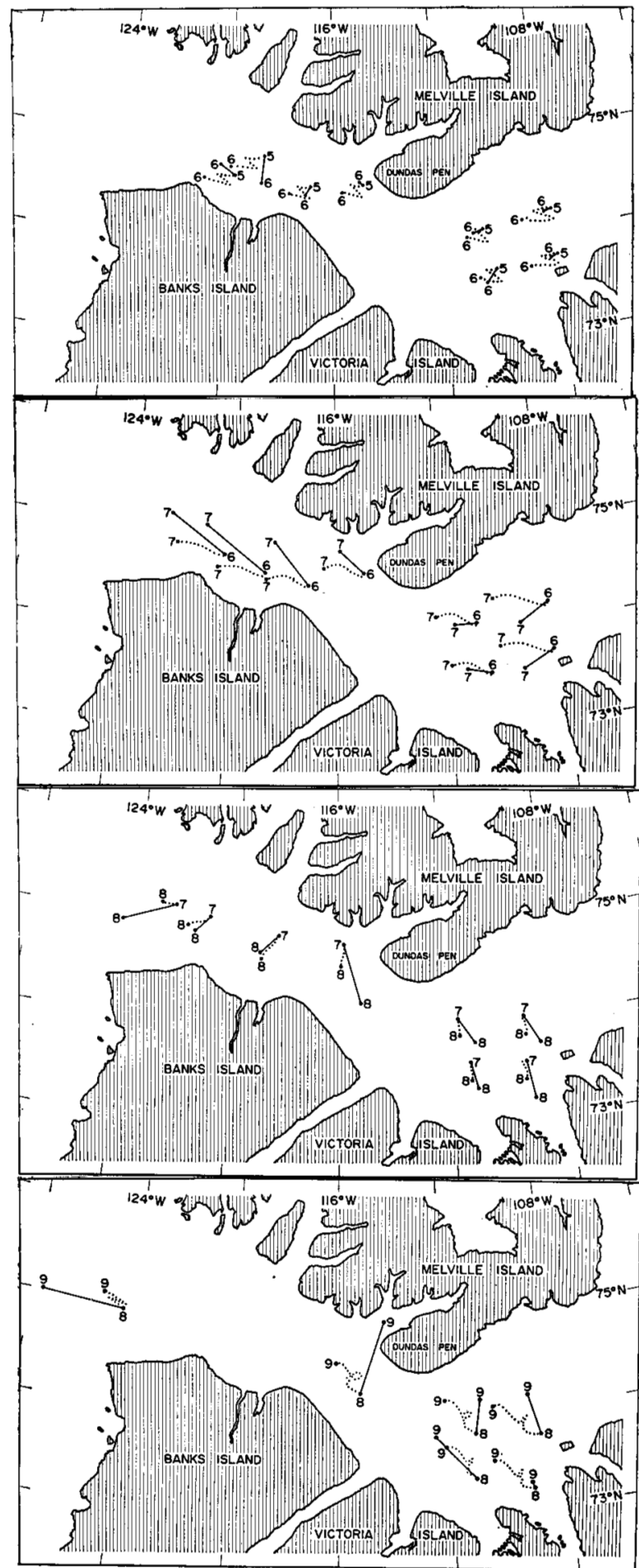

FIG. 4. Comparison of the observed buoy positions on overflight 5 (21 July) and overflight 6 (4 August) with the calculated buoy motion between these dates.

FIG. 5. Comparison of the observed buoy positions on overflight 6 (4 August) and overflight 7 (13 August) with the calculated buoy motion between these dates.

FIG. 6. Comparison of the observed buoy positions on overflight 7 (13 August) and overflight 8 (19 August) to the calculated buoy motion between these dates.

FIG. 7. Comparison of the observed buoy positions on overflight 8 (19 August) and overflight 9 (9 September) to the calculated buoy motion between these dates. 


\section{ACKNOWLEDGEMENTS}

Buoy deployment was made possible by the use of aircraft on charter to the Polar Continental Shelf Project, Canada Department of Energy, Mines and Resources. Determination of the buoy positions was effected by Canadian Armed Forces, Maritime Command. Acknowledgement is also due to Panarctic Oils Ltd. for accommodation at Rea Point and to the Department of the Environment for accommodation at Mould Bay.

\section{REFERENCES}

TAYLOR, J., P. RICHARDS and R. HALSTEAD. 1971. Computer Routines for Surface Generation and Display. Marine Sciences Branch, Department of Energy, Mines and Resources, pp. 1-47.

zUbov, N. N. 1943. Arctic Ice. Translated from the Russian by the U.S. Navy Oceanographic Office and the American Meteorological Society. pp. 355-97. 